\title{
From social security to social investment? Compensating and social investment welfare policies in a life course perspective
}

\author{
Kati Kuitto \\ Finnish Centre for Pensions \\ Contact: kati.kuitto@etk.fi
}

Published in: Journal of European Social Policy 2016, 26(5), 442-459.

(Final accepted manuscript version, accepted for publication on 12 June 2015)

\begin{abstract}
This article contributes to the ongoing debate on the forms and characteristics of social investment policies and their potential trade-off with social security schemes by assessing developments of welfare spending profiles in 23 European welfare states in the 2000s. I argue that if a social investment turn has indeed occurred, it is not necessarily at the cost of the "old" compensatory policies. Instead, social investment policies and their relation to compensating welfare policies alter with regard to policies targeted at different life-stages and to the type of welfare regime. Therefore, the results attest to a path-dependent trend within the welfare regimes, the Nordic countries remaining clear forerunners both in terms of level and dynamics of social investment policies. European social investment strategies manifest mainly in policies targeting childhood and youth, while a trade-off between social investment and compensating policies is evident in working age policies to some degree.
\end{abstract}

Keywords: social investment, social protection, disaggregated welfare expenditure, life course, welfare regimes 


\section{Introduction}

Social investment has not only become an influential notion in the social policy research of recent years but also in the political agenda of the European Union (EU) since the adoption of the Lisbon Strategy in 2000 and the Social Investment Package in 2013 (European Commission, 2013). Advanced welfare states are said to experience a paradigmatic change from an old focus on social security to a novel focus on social investment and activation in reaction to labour market and demographic change in the post-industrial era (Esping-Andersen et al., 2002; Morel et al., 2012c; Hemerijck, 2013). As a political agenda, the social investment strategy is seen as a promising and sometimes also the only possible answer to the challenges of the post-industrial era. Although a lot of evidence exists on welfare policy transformations and on the growing importance of social investment policies as such, there have only recently been attempts to study the "social investment turn" from a macro-comparative perspective (for example Hudson and Kühner, 2009; Nikolai, 2012; Hemerijck et al., 2013; Hemerijck, 2013). Specifically, empirical evidence of the spread and patterns of social investment policies across a greater number of countries is still lacking and in part contradictory, not least because of heterogeneous measures and unspecific conceptualization of social investment policies (De Deken, 2014). The key question from the macro-comparative perspective is how the welfare architecture (i.e., the composition of different policy tools) has changed in the course of the "social investment turn" and whether there is even a path-departing transition towards active welfare policies across welfare regimes (Bonoli, 2013).

This paper investigates the magnitude and forms of the alleged paradigmatic change from passive social security to social investment welfare states in Europe from a macro-comparative perspective by drawing on empirical evidence from welfare expenditure profiles and the way they change over time. Is there really a trend towards a greater emphasis on social investment policies across European welfare states and, if yes, do different welfare regimes pursue such policies in a similar way? Is there a trade-off between social investment policies and "traditional", compensatory social policies? The study thereby pays specific attention to the life-course targets and effects of changes in welfare policies. Much of the social investment literature emphasizes the greater importance and returns of social investment in early stages of life, mainly because of the focus on generating and facilitating human capital (e.g. EspingAndersen, 2002a, Esping-Andersen, 2009; Kvist, 2013; Heckman, 2000). We would therefore expect a "social investment turn" not only to lead to a shift from compensating social security to social investment policies but also possibly to a greater emphasis on policies directed to earlier stages in the life course. In times of "permanent austerity" where expansion of social expenditure seems unlikely, this would result in a double trade-off of welfare policy recalibration: the first between compensating and investment social policies, the other between policies targeted at the young and the elderly.

The empirical analysis of this paper employs the disaggregated expenditure approach. The clear advantage of (social) spending data is that it is widely available for many countries and time periods, but it also indicates important budgetary priorities of governments especially in times of austerity and has therefore been widely used in comparative policy research more 
generally as well. Furthermore, as previous studies have shown, patterns of welfare spending distinguish fundamentally between different types of welfare states. This is especially true for the targeting of social benefits for different populations in need along the life course (Jensen, 2008; Castles, 2009; Kuitto, 2011). Thus, spending profiles indicate differing manifestations of policy preferences. With an appropriate conceptual attribution of what social investment and compensatory social protection spending are, disaggregated welfare spending can therefore be applied for assessing policy shifts in a particularly fruitful way even if there are some caveats associated with the measure and the data (De Deken, 2014).

The framework is applied for analyzing spending trends in 23 European countries from 20002010. If a paradigmatic change has taken place, it should become observable during the 2000s, the "decade of social investment". For most countries, the fact that strict budgetary constraints continue to occur in this decade highlights the value of studying budgetary shifts in welfare spending and should even more effectively indicate intended and possibly contested policy choices. . This study contributes to a more stringent empirical foundation supporting the occurrence of the alleged social investment turn in European welfare states by drawing on spending profiles indicating social investment and compensating policies in differing welfare systems. Additionally, this research points to the concomitant development of welfare policies targeted at different life-stages. By including both the old EU member states and the new Central and Eastern European (CEE) member states, the analysis also provides empirical insights into the welfare policy shifts of the post-communist new member states in the context of the social investment paradigm and allows for comparisons of all European welfare regimes for the first time.

The concepts and the assumed paradigmatic change from compensating social security to social investment in different life-stages are first discussed in the next section. Section Three introduces a conceptualization for measuring social investment and compensating welfare policies in different life-stages by utilizing disaggregated expenditure data. In Section Four, descriptive empirical evidence is used to show that no general "social investment turn" has emerged in the European welfare states, but instead, policy shifts vary both along policies targeted at different life-stages and across welfare regimes. The last section concludes by discussing whether there really is evidence of a social investment turn in the European welfare states and what that means for the role of compensating welfare benefits.

\section{From compensating social security to social investment}

\section{Conceptions and rationales of the "social investment turn"}

In the last decades, a considerable scholarly body of literature has been dedicated to social investment policies and the "new" welfare state. The notion of social investment in the current academic debate was first most notably proposed by Esping-Andersen (1999; 2002) and Giddens (1998) in search for strategies to encounter new social risks, needs and pressures arising from post-industrialization, atypical employment and labour market insecurities, increasing female labour market participation, demographic ageing and costly maturation of 
social security systems (Taylor-Gooby, 2004; Bonoli, 2006; Hemerijck, 2013). Post-war industrial welfare states which were designed first and foremost to protect incomes via cash transfer programs have been said to be insufficiently able to deal with the challenges of the postindustrial era. The social investment strategy can therefore be seen as an alternative paradigm to the Keynesianism of the Golden Age of the welfare state and to the Neoliberalism of the 1980s (Jenson, 2012; see also (Hemerijck, 2012, Hemerijck, 2013). ${ }^{1}$ In the political arena, the notion of social investment or activating welfare state is related to new social democratic ideas put forward most notably by Tony Blair, Gerhard Schröder and Frank Vandenbroucke since mid-1990s, but also came up in the agendas of several international organizations like the World Bank (World Bank, 2001) and the OECD (OECD, 2005).

According to the definition by Morel et al., the social investment approach accounts for postindustrial pressures as it "rests on policies that both invest in human capital development (...), and that help to make efficient use of human capital (...) while fostering greater social inclusion" (Morel et al., 2012a: 2). Pivotal is thus the idea that promoting labour market participation is a social policy goal in itself and that social policy should be viewed as a productive factor fostering employment and economic growth rather than a burden (ibid., an idea also inherent in the Varieties of Capitalism approach; Hall and Soskice, 2001). Old social protection policies are in some views not only seen as incapable of answering new social demands in the post-industrial era but also as a hindrance for effective labour markets and economic growth (cp. Nolan, 2013). Social investment is closely related but not identical to other notions predicting and describing the "new" welfare state such as productive, capacitating, enabling and active social policies. Each of these terms stems from different ideological roots and policy advocates and stress partly different goals while proposing a variety of overlapping instruments (Nolan, 2013).

\section{A trade-off between social investment and compensation?}

The assumed "paradigmatic change" in general implies a shift from protective welfare states with emphasis on ex-post remedies to productive welfare states with focus on ex-ante prevention (De Deken, 2014: 265; Hudson and Kühner, 2009). Aside from the differing ideological foundations of social investment and social protection welfare policies, there are two further reasons to expect a trade-off between both types of policies in terms of spending. The first is related to fiscal pressures; in times of "permanent austerity" welfare policy expansion which causes more fiscal burden is unlikely (Pierson, 2001; Bonoli, 2013: 3). Implementing new welfare policy measures means more costs, and with restricted budgets, expenditure must be cut in another field. The trade-off should be more pronounced the greater

\footnotetext{
${ }^{1}$ For a critical review of the use and misuse of the notion of social investment, see Nolan, 2013. For arguments on how the structure and retrenchment of social insurance programs - for example, by means of stricter conditionality of unemployment benefits - may have contributed to the emergence of the so called new social needs especially stemming from labour market segregation, see for example Emmenegger et al., 2012; De Deken, 2014.
} 
the fiscal pressures are. However, as active, social investment-type policies tend to be less expensive compared to compensating programs like old-age pensions, the costs of the implementation are comparably low. Also, their implementation tends to create less pathdependent implications so that social investment policies are easier to revise than fundamental reforms of compensating schemes. This would relativize the retrenchment pressures for old programs resulting from implementation of social investment instruments.

The second trade-off assumption is based on an argument about the importance of timing and political power relationships for the implementation of social investment policies. According to the crowding-out argument by Bonoli (2013), countries which entered the post-industrial era earlier (and thus where pressures resulting thereof were present early) faced fewer obstacles to implementing active social policies because actors fighting for policies for the new demands of post-industrial societies could rely on the support of the pro-welfare expansion powers (e.g., the Left, trade unions). Late deindustrializing countries, in contrast, had it considerably harder implementing active social policies. The demands for active policies were in strong competition with demands for the preservation of protection levels because of a) the increasing austerity due to maturation of the social security systems and demographic ageing and $b$ ) the growing power of pro-protection electorates such as pensioners. Vote-seeking politicians were therefore defending protection levels rather than favoring the implementation of new social investment policies (Bonoli, 2013: 66-7). The trade-off between social investment and compensating social policies should thus be most pronounced in countries where deindustrialization took place later and where social investment policies have been less prominent in past decades. In the European contest this applies particularly to the Southern European countries but also to the post-communist welfare states. The Nordic welfare states, in contrast, have followed social investment strategies longer and therefore the political and fiscal trade-off between social investment and compensation policies should be less visible in past years.

However, compensating and social investment policies are not diametrically opposed per se and thus, a greater emphasis on social investment policies does not necessarily lead to decreasing importance of compensating policies. According to Esping-Andersen, adequate income maintenance is even a precondition for preventive policies (Esping-Andersen 2002a: 66). Furthermore, the complementarity of compensating and activating measures is particularly visible within the Varieties of Capitalism $(\mathrm{VoC})$ approach with respect to the role of unemployment benefits and active labour market policies (ALMPs). In this view, unemployment insurance encourages employees to acquire and preserve skills needed in specified sectors even in unsecure times (Estevez-Abe et al., 2001). In case of (threat of) unemployment, ALMPs can then complementarily be applied to facilitate labour market (re)entry. Both types of policies are therefore conducive to individual and collective gains. Furthermore, successful social investment strategies may - somewhat paradoxically - even increase the need for income replacement if they lead to higher employment rates and thus a growing need for income replacement in cases of (temporary) labour market exits among previously economically inactive populations.

In general, the patterns of social investment versus compensation policies presumably vary across the welfare regimes. This is also due to the fact that both social investment and 
compensation policies include a range of tools and programs over the life course, which different welfare states emphasize to various degrees. In the following, I discuss how distinguishing between policies targeted at different life-stages may help in assessing welfare state change more generally.

\section{Social investment and compensating policies in the life course perspective}

As the term and definition of social "investment" suggests, policies subsumed under the umbrella of social investment should generate returns for the investor. This idea is clearest with regard to the role of education as an investment in human capital which is expected to pay off in the future in the form of better labour market chances at the individual, and higher employment rates and economic growth at the macro-level. ${ }^{2}$ Furthermore, the idea of returns on investment implies that social investment policies targeted at different phases in the life course also have different gains, the returns of investment in childhood being the greatest (Heckman, 2000; Esping-Andersen, 2002a; Kvist, 2013, 2015). However, as with social security benefits, there are also a variety of social investment policies targeted at populations at different stages of the life course. The life course perspective therefore seems particularly fruitful for assessing possible substantial welfare policy shifts and it is interesting that only very few comparative analyses on social investment policies have focused on this perspective so far (Kvist, 2013). A focus on life-stage-related investment and compensating welfare policies may also contribute to the debate on the politics of new welfare states, as policy measures targeted at different populations also appeal to and affect layers of the electorate with unequal bargaining power (cp. Bonoli and Natali, 2012; Häusermann, 2012).

Although many of the policies subsumed under social investment strategies are overlapping in terms of life course effects, we can identify social investment policies which are targeted at particular life-stages. Childcare and pre-school education constitute an important part of social investment strategies in childhood, as, according to Kvist, succeeding policies rest on the cognitive skills learned in these formative years (Kvist, 2013: 95). Daycare also smoothes out social inequalities, enabling children from socially excluded families to catch up in terms of their social and cognitive skills. Education is the most important policy providing children and youth with general and specific skills which qualify them for the labour market and society in general. On the compensation side, child benefits and family allowances represent a more traditional "old" logic of providing financial support for the needs of children and families.

During the working age, social investment policies consist first and foremost of active labour market tools such as training and employment services, aiming at facilitating human capital and (re)integration to the labour market. However, services for disabled and socially excluded populations can also be considered as capacitating policies in this life-stage. These policies address the needs of the most vulnerable persons in society, those usually ineligible for other

\footnotetext{
${ }^{2}$ However, we can also argue that welfare policies in general always generate positive returns for society, be it in reducing poverty or creating greater equality and social peace (Bonoli 2013: 18; Nolan, 2013: 461-2).
} 
kinds of social benefits or assistance by offering material and institutional help in terms of boarding houses, reception families or treatment for alcohol and drug dependency. Such measures help socially excluded populations to (re-)participate in societal life and in the best case also in the labour market. In doing so, investment in socially excluded peoples arguably contributes to the goals of the EU social investment strategy discussed above. Compensating policies during the working years, in turn, entail a range of income-replacing cash transfers from sick pay and unemployment insurance to parental leave benefits, all aiming primarily at income-securing goals. ${ }^{3}$

For the elderly, old-age pensions and survivor's cash benefits represent traditional compensation policies with enormous volume and political-societal importance. Social investment policies in the third life-stage include care facilities, home help and other social services which capacitate and enable independent living even with increasing fragility and disabilities.

The overlapping character of goals and multiple gains of social investment tools over the life course become obvious in the case of child and elderly care services, for example (Kvist, 2013; De Deken, 2014). Children's daycare can be perceived as a measure for investing in skills formation and is therefore targeted primarily at childhood and youth as it is perceived in this study, but it also plays a great role for the working age population in reconciling work and family (cp. Bonoli, 2013). Similarly, while social care and activation measures for the elderly primarily target older age groups, they also facilitate labour market participation of the working age, particularly female, population by reducing domestic care obligations.

In the next section, I discuss how capacitating, social investment and compensating, social security welfare policies targeted at different life-stages can be operationalized and measured using disaggregated welfare expenditure data for cross-national comparative analyses.

\section{Measuring the "social investment turn"}

In order to trace whether a "paradigmatic change" in welfare policies has actually taken place, we need measures that allow us to make comparisons over as many countries and time periods as possible while being conceptually precise enough to distinguish between capacitating and compensating social policies. Despite its well-known and broadly discussed caveats, social expenditure has two important advantages for this kind of analytical endeavor. Spending profiles indicate the budgetary emphasis of governments and their general welfare policy orientation (Saunders and Klau, 1985; Siegel, 2007; Castles, 2004). De Deken hits the mark by referring to Schumpeter's analogy; "The budget is the skeleton of the state, stripped of all misleading ideologies..." (De Deken, 2014: 260). Especially in times of economic hardship, the

\footnotetext{
${ }^{3}$ In some views, parental leave benefits are seen as a social investment tool aiming at reconciling work and family. Yet its activating or passive impact depends on the length and the conditions of the leave (see also Bonoli, 2013; De Deken, 2014). Therefore, parental leave benefits are considered to be a compensating program here.
} 
allocation of governmental budgets and the costs of social provision become particularly contentious in political debates. Using disaggregated data offers insights into the asymmetries between different domains of welfare policy and makes it possible to account for volatility in the structure of welfare policies over time. Furthermore, modern welfare states clearly cluster in distinct types with regard to their spending profiles (Kautto, 2002; Jensen, 2008; Castles, 2009; Kuitto, 2011, 2015). Spending profiles systematically co-vary with the institutional structure of welfare provision, a fact which attests to the content validity of disaggregated spending in measuring welfare policies.

Some of the previous research on social investment policies, particularly those focusing on broader patterns and trends, has drawn on social expenditure data (see among others Hudson and Kühner, 2009; Tepe and Vanhuysse, 2010; Bonoli, 2010, Bonoli, 2012; Jensen, 2011; Vandenbroucke and Vleminckx, 2011; Nikolai, 2012; Hemerijck, 2013; Hemerijck et al., 2013). Four previous studies - Vandenbroucke and Vleminckx 2011, Nikolai 2012, Hemerijck 2013 and Hemerijck et al. 2013 - explicitly address the question of trends and proportions of expenditure on "new" or "social investment" and "old" welfare policies, though with slightly deviating compositions and denominations of the measures. Regardless of the countries included in the analysis or the time period, all of them end up with rather ambiguous results with respect to the existence and magnitude of a social investment turn.

In composing the indicators for measuring the social investment turn, I distinguish between social investment and compensating spending. Social investment spending reflects governments' emphasis on activating and capacitating strategies by offering public care facilities, supporting active employment strategies and education. Compensating welfare spending, in turn, contains income replacing cash transfers in case of unemployment, old age, sickness, parenting, disability, invalidity and need for non-insurance based social assistance. Such benefits correspond to the social security strategy to address typical risks of income and job loss that were prevalent in the industrial era (cp. "old" and "new" welfare policies by Häusermann 2012 and "service-oriented capacitating" and "benefit-transfer compensating" social spending by Hemerijck 2013). Figure 1 presents the composition of the social investment and compensating social policy measures in three stages of the life-course. The distinction of the spending categories in compensating and social investment is based on the elaboration of the rationale of each type of social policy in the previous section and differs only slightly from the operationalizations by Häusermann (2012) and Hemerijck (2013). While both authors assign maternity and parental leave cash benefits to the "new" (Häusermann) or "service-oriented capacitating" (Hemerijck) policies, I consider family benefits and child allowances as compensating policies in line with the concerns raised by Bonoli (2013) and De Deken (2014) (see Endnote 3). Deviating from previous operationalizations based on the OECD SOCX data, I also include social exclusion spending (cash and in-kind) provided by Eurostat for reasons discussed above. Besides the investment and compensating indices in each life-stage, I also analyse the aggregated indices of social investment and compensating spending over all lifestages. The categories in Figure 1 refer to the disaggregated social, labour market and education 
expenditure data categories offered by Eurostat on an annual basis (Eurostat ESSPROS, Labour market and Education statistics; extracted June 2014). ${ }^{4}$

Using social expenditure data as policy indicators for cross-country comparisons requires adjusting the data for needs pressures because levels of expenditure are highly dependent on populations in need of and eligible for benefits and services (Saunders and Klau, 1985; Clayton and Pontusson, 1998; Huber and Stephens, 2001; Siegel, 2007; Kangas and Palme, 2007; Kuitto, 2011; Vandenbroucke and Vleminckx, 2011; Hemerijck et al., 2013). I therefore account for functional needs pressures through weighting the disaggregated expenditure figures by respective structural and demographic variables. ${ }^{5}$

\footnotetext{
${ }^{4}$ An important spending category that should be included in social investment spending measures in conceptual terms is preventive health care. Health status is named as one of the important factors for capacitating people and combatting poverty according to the current "Towards Social Investment for Growth and Cohesion" strategy of the European Commission and prevention plays a key role in enhancing the overall health of the population (2013). However, as the standard sources for cross-country disaggregated social expenditure data do not allow for distinguishing between preventive and curative health care spending and health care can therefore be classified as neither capacitating nor compensating, health spending is not included in the analysis.

${ }^{5}$ In the absence of exact numbers of (potential) recipients of each welfare policy program, I use proxy variables which come closest to the needs pressures. Those are: Unemployment rate for unemployment and ALMP spending, the ratio of population over 65 years for old for age-related spending, the ratio of population under 16 years for family cash benefits, the ratio of population between 0-6 years for family benefits in kind and the ratio of population between 7-16 years for education spending (cp. Kangas and Palme, 2007). For all other expenditure categories, no weighting was made due to lack of adequate data on recipients for the time period and across the countries. The data for the weighting variables stems from World Bank WDI database and from Eurostat.
} 
Figure 1. Composition of the social investment and compensating welfare policy measures per life-stage

\begin{tabular}{|c|c|c|c|}
\hline Compensating & $\begin{array}{l}\text { Child/family cash } \\
\text { benefits }\end{array}$ & $\begin{array}{l}\text { Unemployment, sickness, } \\
\text { invalidity, social } \\
\text { exclusion cash benefits; } \\
\text { parental leave and birth } \\
\text { allowance cash benefits }\end{array}$ & $\begin{array}{l}\text { Old age and } \\
\text { survivors cash } \\
\text { benefits }\end{array}$ \\
\hline Social investment & $\begin{array}{l}\text { Family benefits in } \\
\text { kind, education }\end{array}$ & $\begin{array}{l}\text { Active labour market } \\
\text { policies, benefits in kind } \\
\text { for socially excluded and } \\
\text { invalidity }\end{array}$ & $\begin{array}{l}\text { Old age benefits } \\
\text { in kind, benefits } \\
\text { in kind for } \\
\text { survivors }\end{array}$ \\
\hline \multicolumn{4}{|l|}{ Life course } \\
\hline & $\begin{array}{l}\text { Childhood and } \\
\text { youth }\end{array}$ & Working age & Old age \\
\hline
\end{tabular}

Note: Expenditure categories according to Eurostat ESSPROS, Labour market policy and Education statistics

Using social expenditure data has some important restrictions though, two of which have to be considered in particular when using the data for identifying (shifts in) policy patterns. First, there is a, in part significant, difference between gross and net social expenditure (Adema and Ladaique, 2015; De Deken, 2014). Direct and indirect taxation has a greater impact on the levels of compensatory than social investment spending in general, but there are also great differences between the tax effects across countries and over time. Consequently, the levels of social investment spending in relation to compensation spending may be under- or over-estimated. Although no longer time series data for disaggregated net social expenditure is available, Eurostat provides figures for gross versus net spending for cash benefits from 2007-2011, giving an indication of the effects. Differences between net and gross spending are particularly high in the Netherlands, Denmark, Sweden, Italy and Finland and lowest in the CEE countries. Benefits affected the most by taxation include unemployment and old age benefits, but in some countries disability benefits as well. Compensating spending as operationalized in this study may thus be overestimated in these countries. Second, the Eurostat data used here does account for public spending without mandated private spending, which make up a considerable share of compensation spending in some countries (De Deken, 2014). In cases of quasi-private schemes, social expenditure is thus underestimated and may distort the picture. Since comparative information on the actual importance of mandated private spending is hard to get, this aspect must remain unaccounted for in this analysis.

The following analysis includes 23 European democracies for which data for the spending categories presented in Figure 1 is available from 2000 on. These countries are: Austria, Belgium, Czech Republic, Denmark, Estonia, Finland, France, Germany, Hungary, Ireland, Italy, Latvia, Lithuania, the Netherlands, Norway, Poland, Portugal, Romania, Slovakia, Slovenia, Spain, Sweden and United Kingdom. 


\section{Trends and patterns of social investment and compensating welfare policies in Europe}

From passive social security towards social investment?

The question of whether the alleged shift towards social investment policies actually has taken place in Europe in the past decade can best be investigated by looking at the ratio of social investment to compensating welfare spending. This measure, which is only seldomly used in comparative studies aiming at identifying policy shifts (e.g. Swank, 2011 on labour market policies), reflects the relative emphasis between social investment and compensating spending. Values over 1 therefore indicate the dominance of social investment over compensating spending. The trends across the welfare regimes are presented in Figure 2. ${ }^{6}$ In general, there is no clear trend towards increasing importance of social investment in the specific mix of welfare spending in the 2000s of such a magnitude which would justify referring to the change as "paradigmatic". The average emphasis of welfare spending has shifted towards social investment slightly in the Nordic, Anglo-Saxon and Conservative regime, while compensating spending has become relatively more important in the Southern European and the CEE regimes. The post-communist welfare states feature an interesting trend of a clearly increasing shift towards social investment in the first half of the 2000s but in all countries except for Poland, the trend reversed clearly thereafter. This may be due to the severity of the economic crisis in the CEE countries. In general, compensating spending gains in importance in several countries during the years of the economic crisis in late 2000s, but this trend is by no means univocal. When comparing unweighted and needs adjusted spending figures, the effect of the economic crisis on levels of unweighted compensating spending occurs only in some countries in the increasing levels of cash benefit spending for the working age population due to increased spending on unemployment benefits. However, this effect is only marginal and incident in countries where levels of unemployment experienced particularly high fluctuation. ${ }^{7}$

Not surprisingly, the social investment-to-compensation spending ratio is still clearly highest in the Nordic welfare regime, followed by the Anglo-Saxon countries. As the UK and Ireland feature completely opposing trends, and as the other countries of the Liberal regime were not

\footnotetext{
${ }^{6}$ Referring to five welfare regimes commonly identified in comparative welfare state research (Esping-Andersen, 1990; Ferrera, 1996). Although the affiliation of the Western European countries with the four welfare regimes is less contested, the CEE countries do not form a unique, homogeneous welfare regime (see for example Cook, 2010; Kuitto, 2011, 2015). For sake of simplicity, though, the CEE countries except for Slovenia are subsumed under "Central Eastern European welfare regime" here. Slovenia clearly shows attributes of the Southern European cluster and is therefore included in the Southern group (ibid.).

${ }^{7}$ The method of adjusting the spending figures by weighting them with the number of (potential) beneficiaries seeks to compensate cross-country variance in spending levels which occur due to simple variation of the number of beneficiaries. This is reasonable, when we are interested in levels (and change) of certain expenditure as indicator for policy emphasis in a cross-country setting. However, if one seeks to filter out or explicitly analyze the effects of macroeconomic cyclical variation or economic crises on social spending - which is not the aim of this study - one should rely on spending figures related either to total expenditure or per capita.
} 
accounted for here, we cannot say much about the development of the Liberal welfare policies. Of all European countries, it is only in Norway and in the very latest years, Denmark, where the spending on social investment policies exceeds the fiscal emphasis on compensating welfare benefits. 
Figure 2. The relation of social investment to compensating welfare spending in 23 European countries, 2000-2010

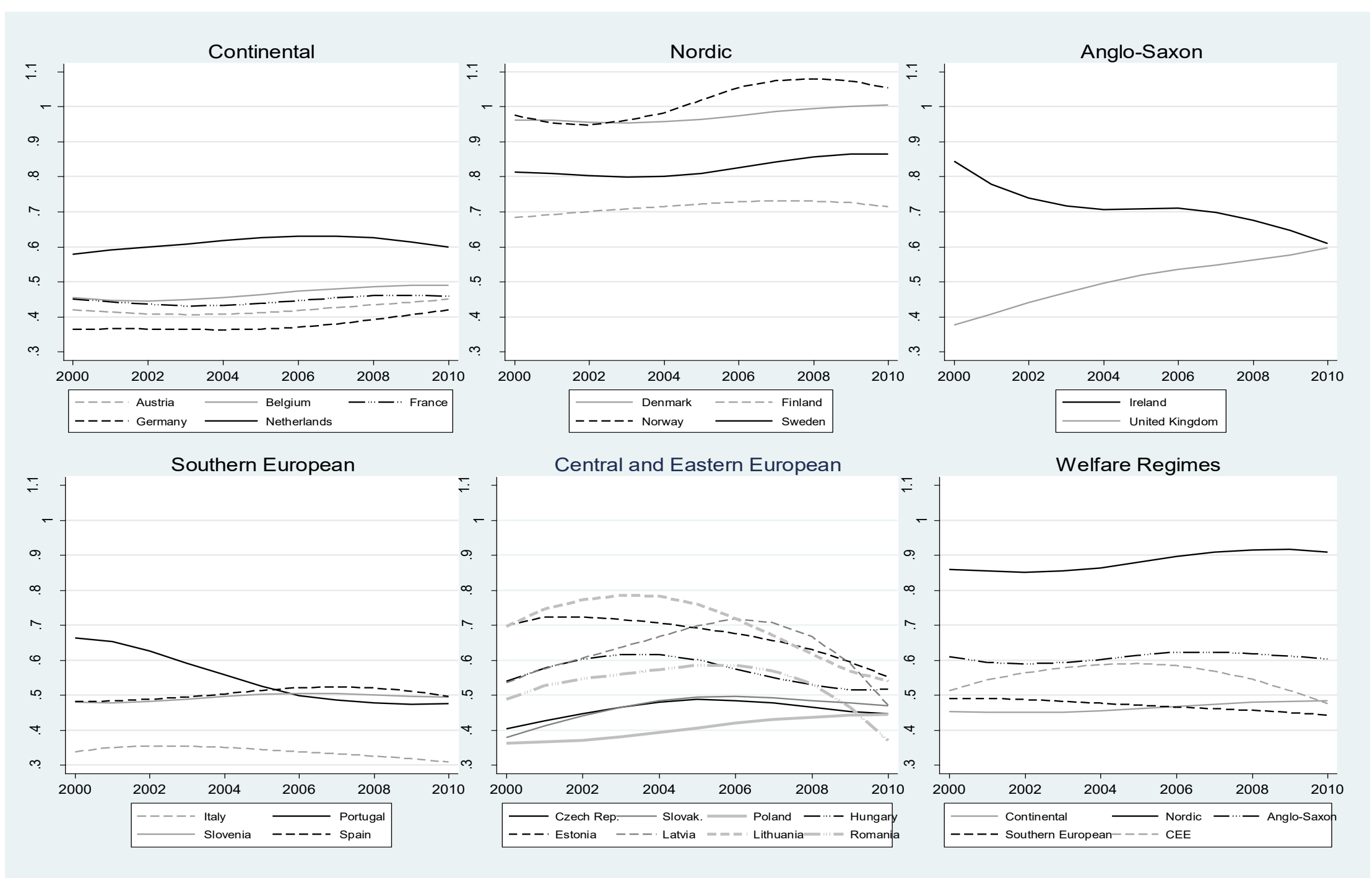


When looking at the development of welfare spending on policies targeted at different lifestages, we find a more nuanced picture. Table 1 presents the change in levels of welfare spending in 2000 and 2010. In all welfare regimes, the average spending in social investment policies is higher at the end of the decade than at the beginning, but the relative change varies greatly both across the regimes and countries and with regard to policies targeted at the different life-stages. Overall, levelling effects are obvious particularly with regard to working and old age spending, as countries which featured lower levels of social investment at the beginning of the period have been catching up with the high spenders. There is a slightly increasing trend of investment in early childhood care and education across all European welfare regimes except for Lithuania and Latvia. Although the Nordic countries clearly show the highest levels of social investment spending on children and youth, the Anglo-Saxon countries including the UK and Ireland have been increasing their investment in this domain the most, proportionally speaking. The relative growth of investment in child care and education is lowest in the CEE and the Southern European welfare regimes, that is, in countries where investment in children and youth targeted policies had already been comparatively low. Given the expected highest future returns of social investment of this kind (Esping-Andersen, 2002a; Kvist, 2013; Heckman, 2000), a social investment turn of the European welfare states might thus appear in form of growing policy emphasis in skills formation and investment in the youngest of society. On average, social investment spending in childhood and youth amounted to $5.10 \%$ of GDP in 2000 and $5.73 \%$ in 2010. Childcare and education spending makes out between a quarter and a third of total welfare expenditure and is the second highest post after spending on compensating old age cash benefits (on average $8.86 \%$ in 2010). In contrast, spending in compensating benefits in childhood and youth has been slightly decreasing in many European countries, with only Ireland, Spain and Portugal having raised cash benefits for children and families remarkably.

The picture of spending emphasis is more mixed with regard to the trends for working age and old age populations. While capacitating welfare policies targeted at working age populations have been the target of increasing fiscal emphasis in all European welfare regimes in the past decade, some countries (e.g., high spenders like the Netherlands and Sweden but also Germany and Italy) have decreased their respective spending for this life-stage consisting mainly of ALMPs. Due to stagnating levels of the Nordic high spenders, the Continental welfare regime has almost reached the levels of working age activation spending previously typical for the Nordic regime. Both regimes are also converging in their levels for compensating spending in this life-stage, resulting from relative cuts in spending for cash benefits in the Nordic countries. The CEE countries feature the highest relative increases for social investment policies for working age populations and have been continuously catching up from their previously low levels, thus investing more in supporting the employment chances of their labour force. In 2010, European countries spent on average $0.95 \%$ of GDP on social investment policies and $3.03 \%$ of GDP on compensating policies targeted at working age population. 
Table 1. Change of social investment and compensating spending from 2000 to 2010 (\% of GDP)

\begin{tabular}{|c|c|c|c|c|c|c|c|c|c|c|c|c|c|c|c|c|c|c|}
\hline & \multicolumn{6}{|c|}{ Childhood and youth } & \multicolumn{6}{|c|}{ Working age } & \multicolumn{6}{|c|}{ Old age } \\
\hline & \multicolumn{3}{|c|}{ Investment } & \multicolumn{3}{|c|}{ Compensation } & \multicolumn{3}{|c|}{ Investment } & \multicolumn{3}{|c|}{ Compensation } & \multicolumn{3}{|c|}{ Investment } & \multicolumn{3}{|c|}{ Compensation } \\
\hline & 2000 & 2010 & $\Delta \%^{\mathrm{a}}$ & 2000 & 2010 & $\Delta \%^{\mathrm{a}}$ & 2000 & 2010 & $\Delta \%^{\mathrm{a}}$ & 2000 & 2010 & $\Delta \%^{\mathrm{a}}$ & 2000 & 2010 & $\Delta \%^{\mathrm{a}}$ & 2000 & 2010 & $\Delta \%^{\mathrm{a}}$ \\
\hline \multicolumn{19}{|l|}{ Continental } \\
\hline Austria & 5.44 & 5.95 & 9.5 & 1.85 & 1.96 & 6.2 & 0.93 & 1.36 & 46.6 & 2.40 & 2.43 & 1.5 & 0.37 & 0.42 & 15.4 & 11.12 & 11.99 & 7.8 \\
\hline Germany & 4.62 & 5.42 & 17.4 & 1.83 & 1.66 & -9.5 & 1.37 & 0.96 & -29.7 & 3.63 & 3.27 & -9.9 & 0.02 & 0.02 & 20.5 & 10.54 & 10.17 & -3.5 \\
\hline France & 5.50 & 6.13 & 11.4 & 1.59 & 1.20 & -24.5 & 1.08 & 1.27 & 17.5 & 2.95 & 3.39 & 14.6 & 0.19 & 0.36 & 87.4 & 10.50 & 11.90 & 13.4 \\
\hline Belgium & 5.61 & 6.25 & 11.3 & 1.47 & 1.38 & -6.3 & 0.79 & 1.54 & 96.6 & 3.83 & 4.99 & 30.3 & 0.12 & 0.14 & 13.6 & 8.90 & 9.54 & 7.2 \\
\hline Netherlands & 4.86 & 5.86 & 20.5 & 0.65 & 0.65 & 0.0 & 2.02 & 1.86 & -7.7 & 3.91 & 4.63 & 18.5 & 0.54 & 0.79 & 45.7 & 8.28 & 8.92 & 7.7 \\
\hline Mean & 5.21 & 5.92 & 14.02 & 1.48 & 1.37 & -6.83 & 1.24 & 1.40 & 24.64 & 3.34 & 3.74 & 11.01 & 0.25 & 0.35 & 36.52 & 9.87 & 10.50 & 6.52 \\
\hline$S T D$ & 0.44 & 0.32 & 4.71 & 0.49 & 0.49 & 11.57 & 0.49 & 0.33 & 49.28 & 0.65 & 1.05 & 15.55 & 0.21 & 0.30 & 31.24 & 1.21 & 1.39 & 6.15 \\
\hline \multicolumn{19}{|l|}{ Nordic } \\
\hline Sweden & 7.11 & 7.68 & 8.0 & 0.73 & 0.65 & -11.2 & 1.94 & 1.73 & -10.8 & 4.66 & 3.04 & -34.8 & 2.19 & 2.01 & -8.4 & 8.11 & 9.12 & 12.4 \\
\hline Denmark & 9.28 & 10.27 & 10.6 & 0.93 & 1.02 & 9.3 & 2.05 & 2.10 & 2.7 & 4.66 & 4.16 & -10.8 & 1.50 & 1.67 & 11.9 & 7.72 & 8.69 & 12.6 \\
\hline Finland & 6.43 & 7.69 & 19.5 & 0.94 & 0.74 & -20.8 & 1.14 & 1.38 & 21.5 & 4.12 & 4.06 & -1.5 & 0.66 & 0.98 & 47.5 & 6.74 & 8.88 & 31.7 \\
\hline Norway & 6.83 & 7.88 & 15.4 & 0.75 & 0.56 & -25.2 & 1.03 & 1.06 & 3.5 & 4.55 & 4.26 & -6.3 & 1.74 & 1.66 & -4.1 & 4.53 & 4.95 & 9.2 \\
\hline Mean & 7.41 & 8.38 & 13.39 & 0.84 & 0.74 & -11.97 & 1.54 & 1.57 & 4.22 & 4.50 & 3.88 & -13.37 & 1.52 & 1.58 & 11.74 & 6.78 & 7.91 & 16.47 \\
\hline$S T D$ & 1.28 & 1.26 & 5.13 & 0.11 & 0.20 & 15.35 & 0.53 & 0.45 & 13.24 & 0.26 & 0.57 & 14.82 & 0.64 & 0.43 & 25.42 & 1.60 & 1.98 & 10.27 \\
\hline \multicolumn{19}{|l|}{ Anglo-Saxon } \\
\hline United Kingdom & 4.33 & 6.11 & 40.9 & 0.82 & 0.74 & -10.3 & 0.34 & 0.55 & 63.2 & 1.70 & 1.49 & -12.1 & 0.35 & 0.44 & 26.5 & 10.13 & 9.03 & -10.8 \\
\hline Ireland & 3.96 & 6.27 & 58.2 & 0.74 & 1.77 & 137.6 & 0.80 & 1.14 & 41.9 & 2.34 & 5.47 & 133.3 & 0.22 & 0.43 & 91.3 & 2.70 & 5.18 & 91.8 \\
\hline Mean & 4.15 & 6.19 & 49.56 & 0.78 & 1.25 & 63.67 & 0.57 & 0.84 & 52.54 & 2.02 & 3.48 & 60.58 & 0.29 & 0.44 & 58.88 & 6.41 & 7.10 & 40.47 \\
\hline$S T D$ & 0.26 & 0.11 & 12.20 & 0.05 & 0.73 & 104.61 & 0.33 & 0.42 & 15.01 & 0.46 & 2.81 & 102.78 & 0.09 & 0.01 & 45.78 & 5.25 & 2.73 & 72.55 \\
\hline \multicolumn{19}{|l|}{ Southern } \\
\hline Spain & 4.28 & 5.25 & 22.7 & 0.09 & 0.19 & 100.8 & 0.96 & 1.09 & 12.9 & 2.89 & 4.65 & 61.2 & 0.20 & 0.66 & 230.0 & 7.77 & 8.75 & 12.6 \\
\hline Italy & 4.24 & 4.62 & 8.9 & 0.37 & 0.37 & 0.7 & 0.54 & 0.39 & -27.6 & 1.29 & 1.55 & 20.0 & 0.08 & 0.13 & 59.0 & 13.00 & 14.78 & 13.7 \\
\hline Portugal & 5.13 & 5.39 & 5.0 & 0.37 & 0.55 & 51.0 & 0.63 & 0.70 & 12.2 & 1.41 & 2.26 & 60.5 & 0.22 & 0.42 & 92.1 & 7.17 & 11.06 & 54.3 \\
\hline Slovenia & 5.76 & 5.76 & 0.0 & 0.93 & 0.74 & -19.8 & 0.22 & 0.67 & 197.4 & 2.52 & 2.66 & 5.6 & 0.09 & 0.08 & -9.0 & 8.93 & 9.47 & 6.1 \\
\hline Mean & 4.85 & 5.25 & 9.12 & 0.44 & 0.46 & 33.19 & 0.59 & 0.71 & 48.72 & 2.03 & 2.78 & 36.84 & 0.15 & 0.32 & 93.01 & 9.22 & 11.02 & 21.70 \\
\hline
\end{tabular}




\begin{tabular}{|c|c|c|c|c|c|c|c|c|c|c|c|c|c|c|c|c|c|c|}
\hline$S T D$ & 0.73 & 0.48 & 9.76 & 0.35 & 0.24 & 54.02 & 0.30 & 0.29 & 100.92 & 0.80 & 1.33 & 28.33 & 0.07 & 0.27 & 100.54 & 2.63 & 2.69 & 22.02 \\
\hline \multicolumn{19}{|l|}{ CEE } \\
\hline Czech Republic & 3.51 & 3.93 & 11.8 & 0.55 & 0.09 & -83.1 & 0.09 & 0.38 & 313.4 & 2.86 & 2.47 & -13.5 & 0.41 & 0.24 & -41.5 & 6.40 & 7.53 & 17.7 \\
\hline Estonia & 5.03 & 5.05 & 0.4 & 0.64 & 0.46 & -28.0 & 0.07 & 0.38 & 447.7 & 1.63 & 2.39 & 46.3 & 0.14 & 0.09 & -34.2 & 5.17 & 6.54 & 26.5 \\
\hline Hungary & 4.55 & 4.86 & 6.7 & 1.28 & 1.28 & 0.2 & 0.22 & 0.73 & 239.8 & 1.75 & 1.91 & 9.2 & 0.44 & 0.56 & 28.3 & 6.55 & 8.39 & 28.2 \\
\hline Latvia & 5.01 & 4.53 & -9.6 & 0.62 & 0.27 & -56.5 & 0.13 & 0.82 & 551.0 & 1.34 & 2.54 & 90.2 & 0.14 & 0.23 & 68.6 & 7.87 & 8.12 & 3.2 \\
\hline Lithuania & 5.08 & 5.03 & -1.0 & 0.18 & 0.18 & -0.8 & 0.35 & 0.54 & 55.6 & 1.57 & 2.79 & 77.7 & 0.18 & 0.21 & 18.8 & 6.36 & 7.02 & 10.4 \\
\hline Poland & 4.12 & 4.58 & 11.1 & 0.46 & 0.28 & -38.9 & 0.08 & 0.70 & 783.9 & 1.95 & 1.68 & -13.9 & 0.07 & 0.05 & -22.2 & 9.36 & 9.79 & 4.7 \\
\hline Romania & 3.11 & 3.49 & 12.1 & 0.54 & 0.64 & 17.8 & 0.06 & 0.07 & 16.0 & 1.16 & 1.38 & 19.5 & 0.03 & 0.04 & 25.7 & 4.98 & 7.60 & 52.7 \\
\hline Slovakia & 3.42 & 3.88 & 13.4 & 0.83 & 0.84 & 1.4 & 0.10 & 0.36 & 247.1 & 3.33 & 2.30 & -31.0 & 0.39 & 0.39 & 0.5 & 5.88 & 6.45 & 9.8 \\
\hline Mean & 4.23 & 4.42 & 5.63 & 0.64 & 0.51 & -23.48 & 0.14 & 0.50 & 331.81 & 1.95 & 2.18 & 23.07 & 0.22 & 0.23 & 5.50 & 6.57 & 7.68 & 19.13 \\
\hline$S T D$ & 0.80 & 0.59 & 8.23 & 0.32 & 0.40 & 34.45 & 0.10 & 0.25 & 255.74 & 0.76 & 0.48 & 44.49 & 0.16 & 0.18 & 37.15 & 1.44 & 1.10 & 16.45 \\
\hline Mean all & 5.10 & 5.73 & 13.23 & 0.83 & 0.79 & -0.43 & 0.74 & 0.95 & 134.55 & 2.72 & 3.03 & 19.77 & 0.45 & 0.52 & 33.19 & 7.77 & 8.86 & 18.23 \\
\hline STD all & 1.37 & 1.53 & 13.90 & 0.48 & 0.53 & 46.21 & 0.64 & 0.54 & 211.21 & 1.17 & 1.21 & 41.46 & 0.57 & 0.56 & 57.05 & 2.39 & 2.24 & 22.18 \\
\hline
\end{tabular}

Notes: a Change 2000-2010 in percentage of the levels in 2000. 
The level of social investment in old age in terms of care facilities, home help and other social services for elderly and survivors is over three times higher in the Nordic welfare states (1.58 $\%$ on average in 2010) than in the regime with the second highest levels of spending, that of the Anglo-Saxon countries ( $0.44 \%$ in 2010). ${ }^{8}$ The remarkable service-orientation of old-age targeted policies thus remains the trademark of the Nordic regime. However, except for most of the CEE countries as well as Sweden and Norway, all other countries have strengthened their financial emphasis on social investment policies in old age and have done so to a greater extent than in compensating policies. This suggests a general trend towards a more capacitating approach in many welfare states in dealing with the demographic ageing of society. The overall relevance of social investment spending in old age remains low, though, with $0.52 \%$ of GDP spent on average in social services, home help etc. for the elderly in contrast to $8.86 \%$ on cash pensions (2010).

The divide between the service- and activation-oriented Nordic countries and the social security-oriented Conservative and Southern European welfare states thus not only persists with respect to welfare policies targeted at old age but also more broadly throughout the whole life course of the population. ${ }^{9}$ The spending gap between social investment and compensating measures targeted at working age populations is getting smaller in both the Nordic countries and the CEE countries. However, while this is due to decreasing cash transfer spending in the Nordic regime, the CEE countries are indeed investing more in ALMPs, albeit still at a low level. The gap between social investment and compensating spending for elderly has only become smaller in the Anglo-Saxon and Southern European welfare states, and even here only moderately. In general, the gap between social investment and compensating welfare spending continues to be lowest in the Nordic welfare states (11.31\% to $12.53 \%$ in 2010 ) and still highest in the Continental welfare states (7.53 \% to $15.62 \%$ in 2010). Except for compensation spending in the Anglo-Saxon group consisting of the United Kingdom and Ireland and to a lesser degree also the Southern European regime cluster, the within-regime variation is lower than the crosscountry variation in all spending categories. Welfare regimes thus still feature differing spending profiles with respect to both the relation of social investment and social security measures and the primary target groups during the life-course. This observation seems to support the path dependency assumption and the relative rigidity of the European welfare models.

\section{A trade-off between social investment and social protection?}

Even in the absence of a clear paradigmatic change towards a social investment welfare state in terms of spending, the question remains whether the observed shifts towards more social

\footnotetext{
${ }^{8}$ However, expenditure on elderly care are potentially underestimated in some of the Continental European countries (Germany, France, Belgium and the Netherlands), where long-term care is largely financed out of health care budget, thus not showing in the spending figures presented in this study (cp. De Deken, 2014: 273).

${ }^{9}$ Because the potential differences in levels of gross and net social expenditure are likewise high in both the Nordic and the Continental countries, tax effects are not likely to distort the overall picture.
} 
investment spending have been accompanied by cuts in spending on compensating cash benefit schemes. According to the resource competition hypothesis, at least in times of tight budgetary constraints as has been the case in the 1990s and 2000s, "a shift in budgetary resources to new social spending might explain downward pressure in old cash benefit programs" (Vandenbroucke and Vleminckx, 2011: 458; see also Cantillon, 2011). Figure 3 plots the change in social investment and compensating spending from 2000-2010 in the 23 countries. Only in six countries, namely the UK, Germany, Slovakia, Sweden and to a minor extent also Norway and Poland, has increasing relevance of social investment spending been accompanied by decreasing levels of compensation spending. A great majority of the European welfare states spend more on both types of programs relative to GDP.

Figure 3. Social investment and compensating welfare spending (weighted, \% of GDP), chance from 2000 to 2010

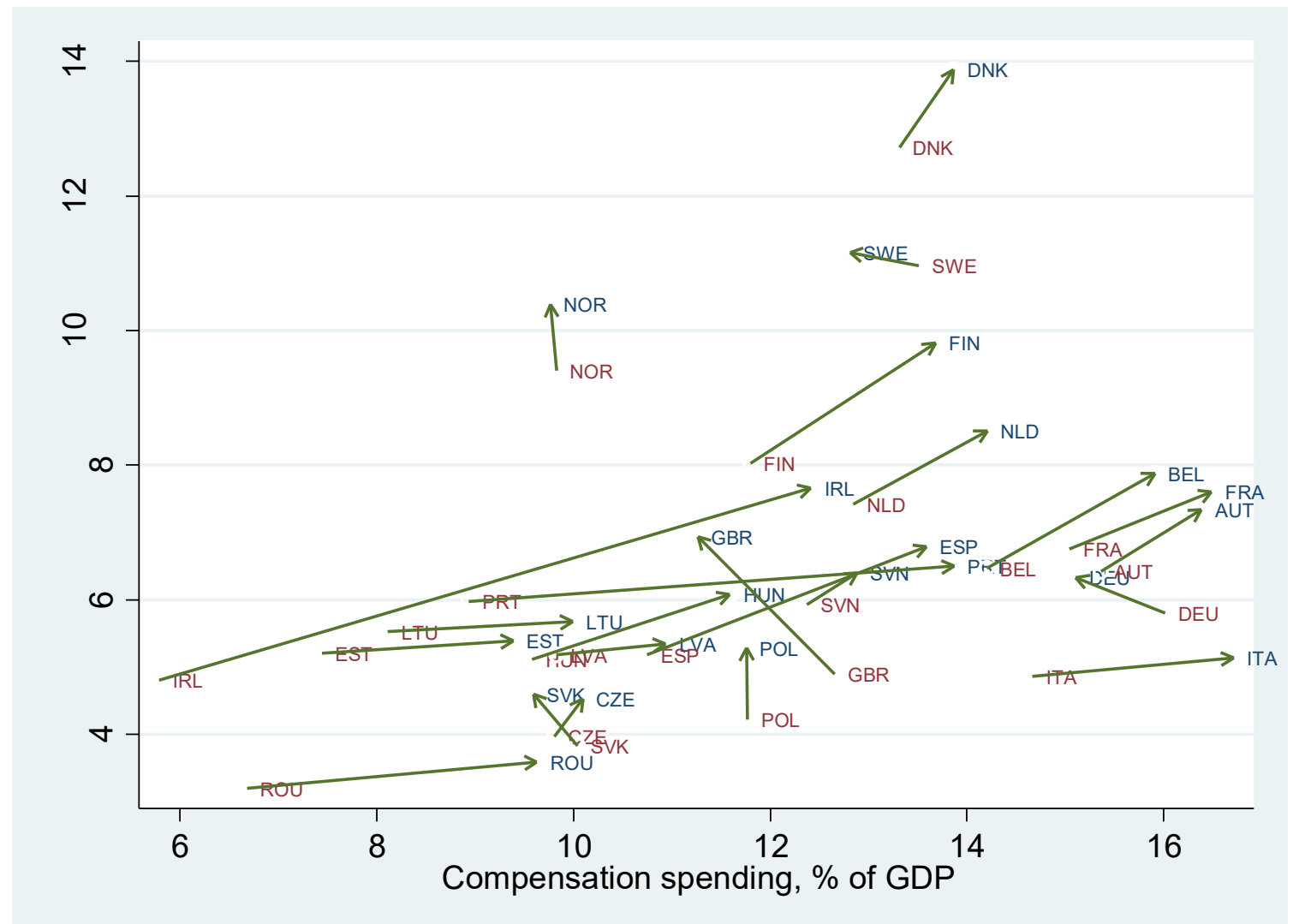

Source: Eurostat, own calculations.

The argument about a possible trade-off between social investment and compensating cash transfer programs only indirectly implies alternating levels of expenditure, though. The rationale behind the trade-off-argument is that governments reduce the generosity of compensating social security benefits for two reasons; first, there is an intentional policy shift from income replacement towards activation, and second, additionally or alternatively, scarce budgetary frames force governments to reduce cash benefits while spending more on social investment policies in order to meet new social needs. Consequently, income replacing cash benefits should become less generous, resulting in re-commodification (cp. Vandenbroucke 
and Vleminckx, 2011). This should be particularly obvious in social protection schemes targeted at the working age population, as the generosity of unemployment and sickness benefit schemes is less dependent on long-term contributory effects and path-dependency and is therefore easier to adjust in the short- and middle-term perspective than, for example, public pension schemes. Also, the idea of an "activation turn" is most prominent with regard to policies affecting labour market participation (Bonoli, 2013). Figure 4 plots changes in social investment spending for the working age population from 2000 to 2010 against changes in the average generosity of unemployment and sickness benefits. Working age benefit generosity is measured by the average of the benefit generosity index introduced by Scruggs $(2007 ; 2014)$ for unemployment and sickness insurance. The benefit generosity index combines the average level of cash benefits (replacement rate) with qualification criteria and duration of the benefits and thus indicates the overall generosity of the respective social insurance program (for a detailed description of the index, see Scruggs, 2014). The data stems from the Comparative Welfare Entitlements Dataset CWED 2 (Scruggs et al., 2014). ${ }^{10}$

Figure 4. Social investment spending and benefit generosity for working age, chance from 2000 to 2010

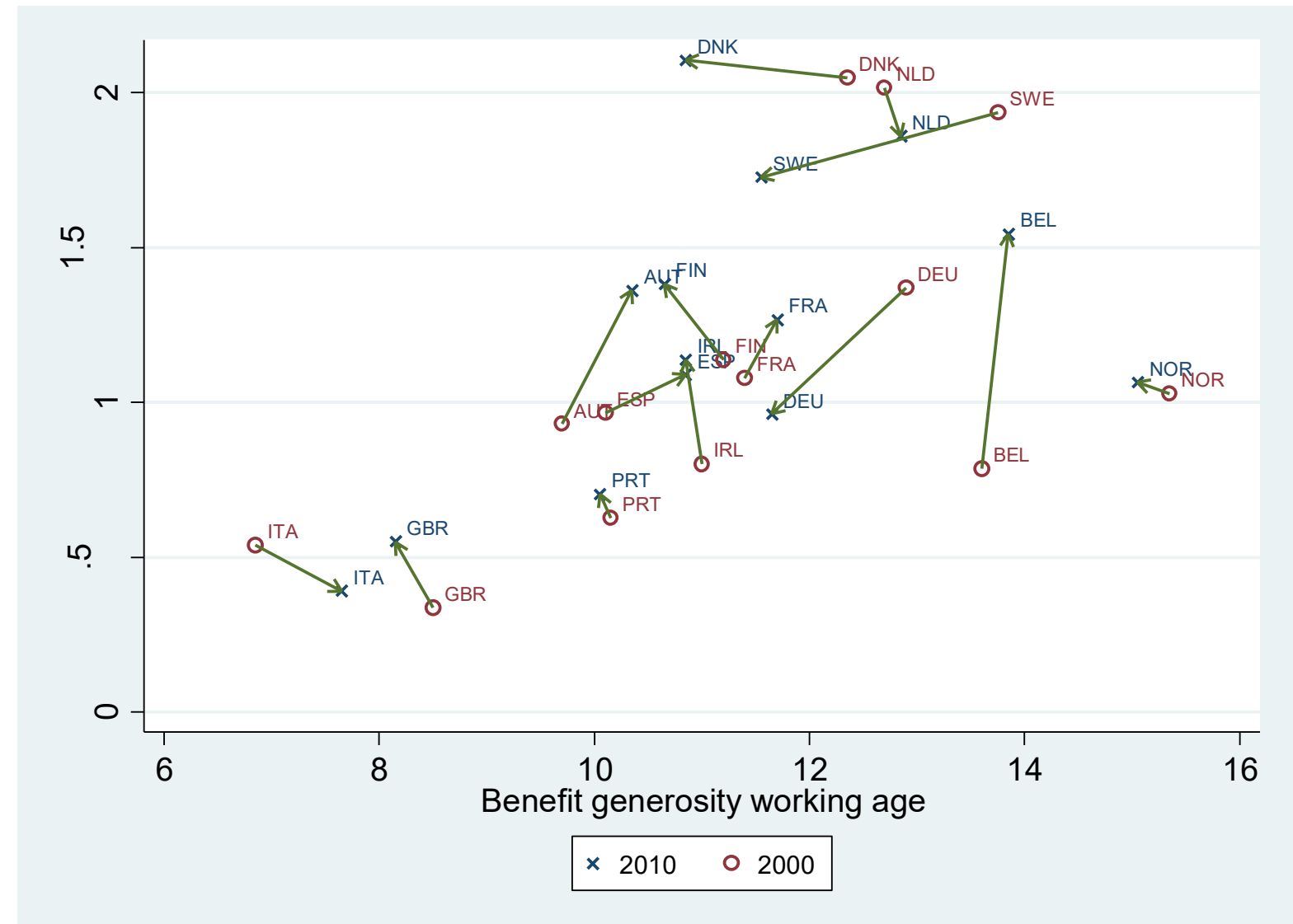

Source: Eurostat and CWED2 (Scruggs et al., 2014), own calculations.

The evidence in Figure 4 is highly mixed. Whereas increases in social investment spending for working age populations have been accompanied by sinking generosity of income-

${ }^{10}$ Data for certain parameters of the generosity index for the CEE countries is still lacking. Therefore, the following analysis includes only the Western European states. 
compensating benefits in six quite different Western European welfare states (Denmark, Finland, Norway, Ireland, Portugal and Great Britain), the opposite is true for Italy and the Netherlands. In Austria, Spain and Belgium, both benefit generosity and social investment spending have been increasing, and finally, Sweden and Germany feature a retrenchment in both aspects. Therefore, it is evident that the developments of welfare policies for working age populations are highly diversified across Europe. Moreover, although a trade-off between social investment and compensation policies is prevalent in some countries, it takes place at very different levels and in differing institutional and economic contexts.

In sum, where social investment has gained ground in policies directed at different life-stages, it has not come at the cost of compensatory policies. Growing emphasis on a social investment type of program targeted at one life-stage is not negatively correlated with spending on programs targeted at other life-stages. The overall increasing trend of total social expenditure suggests that despite the strict budgetary limits and permanent austerity during the 2000s, no retrenchment of welfare state has taken place (see also Kuitto et al., 2012). Consequently, there is no indication of "resource competition" or trade-offs between compensating and social investment welfare policies (Cantillon, 2011). Figures 3 and 4 show that rather than a trade-off, there is (still) a distinction between those countries spending less on welfare policies in general (most of the CEE countries) and those spending more in both compensating and social investment policies and offering more generous benefits. Moreover, the growth of compensating spending has been higher in the low-spending countries, probably resulting from greater demand for social protection and the need for catching up in terms of welfare policies in general. ${ }^{11}$ The absence of a clear trade-off is in line with the findings by Hemerijck (2013: 266) and Vandenbroucke and Vleminckx (2011: 460). The latter authors additionally show that if anything, there seems to be a trade-off between increasing spending on health care - a variable which is neglected here - and spending on traditional cash transfers.

\section{Conclusion - much ado about nothing?}

The results of this study largely confirm findings of many previous studies, stating that no uniform shift towards a social investment welfare state can be observed in cross-country comparison at least in terms of governmental spending, confirming the overall findings of previous studies on the so-called social investment turn (cp. Morel et al., 2012b; Nikolai, 2012; Hudson and Kühner, 2009; Vandenbroucke and Vleminckx, 2011; Hemerijck, 2013; Hemerijck et al., 2013). However, the detailed empirical evidence provided in this analysis refines the findings of previous studies in two ways. First, where social investment policies have gained more budgetary importance, those shifts have not come at cost of compensating welfare policy spending. The latter is only partly true for policies targeted at the working age population though. The empirical evidence thus does not support the resource compensation hypothesis or the assumption that social investment measures would go hand in hand with re-

\footnotetext{
${ }^{11}$ In the CEE countries, this might also be an effect of the EU accession process.
} 
commodification and retrenchment (cp. Vandenbroucke and Vleminckx, 2011; Nolan, 2013). One explanation for the absence of such a trade-off (and consequently, of a paradigmatic change within the European welfare states) can be found in the dynamics of the impacts of social investment and compensatory policies. Whereas investing in human capital generation and capacitation seems attractive to large parts of the electorates and political agencies, cutting benefits particularly in social insurance based systems easily raises political opposition (Häusermann, 2012; Vis, 2010). Consequently, it is easier for governments to implement active welfare policies and social services than to cut income replacing benefits. Another explanation relying on a rather strong assumption of rational actors would be that policy makers acknowledge the future gains of social investment strategies in the middle and long run and hope that capacitating welfare policies will lead to diminishing need for compensating benefits in the future, so that no need for risky benefit cuts in the present appears. Also, in EspingAndersen's words, "income security is a precondition for an effective social investment strategy" (Esping-Andersen, 2002b: 5), and effective social investment strategy may also increase the need for income replacement for previously inactive persons entering the labour market with its risks.

Second, European welfare states still differ with regard to their overall commitment to welfare in general and their emphasis on different welfare policy objectives especially in the way policies are targeted at populations throughout different life-stages. The Nordic model remains thereby most clearly committed to capacitating, social investment policies, investing even more especially in childhood- and youth-related policies. In the Anglo-Saxon welfare states, too, social investment policies gain ground especially by means of investment in education in childhood and youth, but the actual mix of policy tools is different from the universal one of the Nordic countries. Hints of an increasing importance of social investment strategies can also be found in the Conservative and Southern European welfare states, but this has not fundamentally challenged the dominance of social insurance based income transfers cumulated especially for old age and working age populations in the Bismarckian systems (but see also Palier, 2010). The CEE countries remain rudimentary in terms of both social investment and compensating welfare policies, although their investment in labour market activation policies and thus their active support for working age populations has increased during the past decade. However, the CEE countries perform weakest in increasing human capital investment in childhood and youth, demonstrating that the welfare policies in CEE are less sustainable in the middle and long run than those of the other European countries when considering the anticipated pay-offs of social investment in children and youth and its inherent virtue.

Altogether, the regime approach still seems valid for European welfare even when looking at the relative importance of social investment and compensating welfare expenditure. Reasons for the differing spending emphasis as well as for the varying new welfare policy instruments may be found in the very same socio-economic, political-institutional and cultural factors that constitute the regimes in the first place. Path dependencies, on the one hand, and intra-regime diffusion, on the other hand, may play a significant role in the adaption of social investment measures, leading to new welfare policy strategies regime-wise. 
Despite the lacking overall shift from compensating to social investment policies in terms of welfare spending, the kind of macro-comparative analysis performed in this paper may, of course, fail at identifying more nuanced institutional policy change. As dimensions of social investment policies are often ambivalent and even contradictory to some degree in addition to the fact that they were introduced in various phases reflecting different functional needs pressures in past decades, the face of already implemented social investment policies is probably more prevalent than what is revealed by plain relations of expenditure (cp. Vandenbroucke and Vleminckx, 2011: 452). Moreover, it will be interesting to see how new welfare policies have evolved in the medium-term after the recent economic crisis. As the results show, income compensating policies gained renewed importance in some countries during and after the crisis. Real policy changes as a consequence of the crisis may, however, manifest themselves in spending profiles only in the medium term. The kind of descriptive empirical evidence provided in this study offers a differentiated starting point for causal analyses on the impacts of macroeconomic cyclical factors, structural change and politics on shifts in welfare policies targeted at and effecting different life-stages. Finally, looking at governmental policy outputs in terms of spending priorities makes just half the case. The same proportion of spending may be deployed at a differing degree of efficiency depending on the institutional, administrational and cultural features in different countries (Castles, 2013; Hemerijck et al., 2013). Although the actual impact of social investment policies has been contested in many studies and the current achievements of activation and capacitating strategies show a rather sobering balance (Cantillon, 2011; Vandenbroucke and Vleminckx, 2011; van Lancker and Ghysels, 2014), in the longer run, paradigmatic change - or the lack of it - may also manifest itself in social outcomes.

\section{Acknowledgements}

The research presented in this study was supported by a research grant from the German Research Foundation DFG (Grant No. JA638/12-2, "Welfare policies in the enlarged Europe"). The author would like to thank participants of the Stream "Social investment" at the ESPAnet Conference 2013 and the "Assessing the social investment strategy" conference at IDHEAP, Lausanne 2014 as well as Detlef Jahn, Nils Düpont, Jan Helmdag, Ashley Gongaware and the two anonymous reviewers for their helpful comments on earlier versions of the study. 


\section{References}

Adema, W. and Ladaique, M. (2005) Net Social Expenditure, 2005 Edition. More comprehensive measures of social support. OECD Social, Employment and Migration Working Papers No. 29. Paris: OECD.

Bonoli, G. (2006) 'New Social Risks and the Politics of Post-Industrial Social Policies', in K. Armingeon and G. Bonoli (eds) The Politics of Post-industrial Welfare States: Adapting Postwar Social Policies to New Social Risks, pp. 3-26. London, New York: Routledge.

Bonoli, G. (2010) 'The Political Economy of Active Labor-Market Policy', Politics \& Society 38(4): 435-57.

Bonoli, G. (2012) 'Active labour market policy and social investment: a changing relationship', in N. Morel, B. Palier and J. Palme (eds) Towards a Social Investment Welfare State?: Ideas, Policies and Challenges, pp. 181-204. Bristol: The Policy Press.

Bonoli, G. (2013) The Origins of Active Social Policy: Labour Market and Childcare Polices in a Comparative Perspective. Oxford: Oxford University Press.

Bonoli, G. and Natali, D. (eds.) (2012) The Politics of the New Welfare State. Oxford: Oxford University Press.

Cantillon, B. (2011) 'The paradox of the social investment state: growth, employment and poverty in the Lisbon era', Journal of European Social Policy 21(5): 432-49.

Castles, F. G. (2004) The future of the welfare state: Crisis myths and crisis realities. Oxford: Oxford Univ. Press.

Castles, F. G. (2009) ‘What Welfare States Do: A Disaggregated Expenditure Approach', Journal of Social Policy 38(1): 45-62.

Castles, F. G. (2013) 'The Real Issue for Future Comparative Policy Research: Does Government Matter?', in K. Armingeon (ed.) Staatstätigkeiten, Parteien und Demokratie: Festschrift für Manfred G. Schmidt, pp. 185-204. Wiesbaden: Springer VS.

Clayton, R. and Pontusson, J. (1998) ‘Welfare-State Retrenchment Revisited: Entitlement Cuts, Public Sector Restructuring, and Inegalitarian Trends in Advanced Capitalist Societies', World Politics 51(1): 67-98.

Cook, L. J. (2010) 'Eastern Europe and Russia', in F. G. Castles, S. Leibfried, J. Lewis, H. Obinger and C. Pierson (eds) The Oxford Handbook of the Welfare State, pp. 671-86. Oxford: Oxford University Press.

De Deken, J. (2014) 'Identifying the skeleton of the social investment state: defining and measuring patterns of social policy change on the basis of expenditure data', in B. Cantillon and F. Vandenbrouck (eds) Reconciling Work and Poverty Reduction: How Successful are European Welfare States?, pp. 260-85. Oxford: Oxford University Press.

Esping-Andersen, G. (1990) The Three Worlds of Welfare Capitalism. Princeton: Princeton University Press.

Esping-Andersen, G. (1999) Social Foundations of Postindustrial Economies. Oxford: Oxford University Press.

Esping-Andersen, G. (2002a) 'A Child-Centered Social Investment Strategy', in G. EspingAndersen, D. with Gallie, A. Hemerijck and J. Myles (eds) Why We Need a New Welfare State, pp. 26-67. Oxford: Oxford University Press.

Esping-Andersen, G. (2002b) 'Towards the Good Society, Once Again?', in G. EspingAndersen, D. with Gallie, A. Hemerijck and J. Myles (eds) Why We Need a New Welfare State, pp. 1-25. Oxford: Oxford University Press.

Esping-Andersen, G. (2009) The incomplete revolution: Adapting to women's new roles. Cambridge: Polity Press. 
Esping-Andersen, G., with Gallie, D., Hemerijck, A. and Myles, J. (eds.) (2002) Why We Need a New Welfare State. Oxford: Oxford University Press.

Estevez-Abe, M., Iversen, T. and Soskice, D. W. (2001) 'Social Protection and the Formation of Skills: A Reinterpetation of the Welfare State', in P. A. Hall and D. W. Soskice (eds) Varieties of Capitalism: The Institutional Foundations of Comparative Advantage, pp. 145-83. Oxford: Oxford University Press.

European Commission (2013) Towards Social Investment for Growth and Cohesion - including implementing the European Social Fund 2014-2020: Communication from the Commission to the European Parlament, the Council, the European Economic and Social Committee and the Committee of the Regions. Brüssel.

Ferrera, M. (1996) 'The "Southern" Model of Welfare in Social Europe', Journal of European Social Policy 6(1): 17-37.

Giddens, A. (1998) The Third Way: The Renewal of Social Democracy. Cambridge: Polity Press.

Hall, P. A. and Soskice, D. W. (eds.) (2001) Varieties of Capitalism: The Institutional Foundations of Comparative Advantage. Oxford [England], New York: Oxford University Press.

Häusermann, S. (2012) 'The Politics of Old and New Social Policies', in G. Bonoli and D. Natali (eds) The Politics of the New Welfare State, pp. 111-32. Oxford: Oxford University Press.

Heckman, J. J. (2000) 'Policies to foster human capital', Research in Economics 54(1): 3-56.

Hemerijck, A. (2012) 'Two or three waves of welfare state transformation?', in N. Morel, B. Palier and J. Palme (eds) Towards a Social Investment Welfare State?: Ideas, Policies and Challenges, pp. 33-60. Bristol: The Policy Press.

Hemerijck, A. (2013) Changing Welfare States. Oxford: Oxford University Press.

Hemerijck, A., Dräbing, V., Vis, B., Nelson, M. and Soentken, M. (2013) European Welfare States in Motion. Amsterdam.

Huber, E. and Stephens, J. D. (2001) Development and Crisis of the Welfare State: Parties and Policies in Global Markets. Chicago: University of Chicago Press.

Hudson, J. and Kühner, S. (2009) 'Towards productive welfare? A comparative analysis of 23 OECD countries', Journal of European Social Policy 19(1): 34-46.

Jensen, C. (2008) 'Worlds of welfare services and transfers', Journal of European Social Policy 18(2): 151-62.

Jensen, C. (2011) 'The forgotten half: analysing the politics of welfare services', International Journal of Social Welfare 20(4): 404-12.

Jenson, J. (2012) 'Redesigning citizenship regimes after neoliberalism: moving towards social investment', in N. Morel, B. Palier and J. Palme (eds) Towards a Social Investment Welfare State?: Ideas, Policies and Challenges, pp. 61-87. Bristol: The Policy Press.

Kangas, O. and Palme, J. (2007) 'Social rights, structural needs and social expenditure: a comparative study of 18 OECD countries 1960-2000', in J. Clasen and N. A. Siegel (eds) Investigating Welfare State Change: The 'Dependent Variable Problem' in Comparative Analysis., pp. 106-29. Cheltenham: Elgar.

Kautto, M. (2002) 'Investing in Services in West European Welfare States', Journal of European Social Policy 12(1): 53-65.

Kuitto, K. (2015) Post-Communist Welfare States in European Context: Patterns of Welfare Policies in Central and Eastern Europe. Cheltenham: Edward Elgar Publishing (in preparation).

Kuitto, K. (2011) 'More than just money: Patterns of disaggregated welfare expenditure in the enlarged Europe', Journal of European Social Policy 21(4): 348-64.

Kuitto, K., Jahn, D. and Düpont, N. (2012) Welfare policy institutions in the enlarged EU convergence, divergence or persistence? Greifswald Comparative Politics Working paper No. $1 / 2012$. 
Kvist, J. (2013) 'The post-crisis European social model: developing or dismantling social investments?', Journal of International and Comparative Social Policy 29(1): 91-107.

Kvist, J. (2015) 'A framework for social investment strategies: Integrating generational, life course and gender perspectives in the EU social investment strategy', Comparative European Politics 13(1): 131-49.

Morel, N., Palier, B. and Palme, J. (2012a) 'Beyond the welfare state as we knew it?', in N. Morel, B. Palier and J. Palme (eds) Towards a Social Investment Welfare State?: Ideas, Policies and Challenges, pp. 1-30. Bristol: The Policy Press.

Morel, N., Palier, B. and Palme, J. (2012b) 'Social investment: a paradigm in search of a new economic model and political mobilisation', in N. Morel, B. Palier and J. Palme (eds) Towards a Social Investment Welfare State?: Ideas, Policies and Challenges, pp. 353-76. Bristol: The Policy Press.

Morel, N., Palier, B. and Palme, J. (eds.) (2012c) Towards a Social Investment Welfare State?: Ideas, Policies and Challenges. Bristol: The Policy Press.

Nikolai, R. (2012) 'Towards social investment? Patterns of public policy in the OECD world', in N. Morel, B. Palier and J. Palme (eds) Towards a Social Investment Welfare State?: Ideas, Policies and Challenges, pp. 91-115. Bristol: The Policy Press.

Nolan, B. (2013) ‘What use is 'social investment'?', Journal of European Social Policy 23(5): 45968.

OECD (2005) Extending Opportunities: How Active Social Policy Can Benefit Us All. Paris: Organisation for Economic Co-operation and Development.

Palier, B. (2010) 'The Long Conservative Corporatist Road to Welfare Reforms', in B. Palier (ed.) A Long Goodbye to Bismarck?: The Politics of Welfare Reforms in Continental Europe, pp. 333-87. Amsterdam: Amsterdam University Press.

Palme, J., Nelson, K., Sjöberg, O. and Minas, R. (2009) European Social Models, Protection and Inclusion. Stockholm.

Pierson, P. (2001) 'Coping with Permanent Austerity: Welfare State Restructuring in Affluent Democracies', in P. Pierson (ed.) The New Politics of the Welfare State, pp. 410-56. Oxford: Oxford University Press.

Saunders, P. and Klau, F. (eds.) (1985) The role of the public sector: causes and consequences of the growth of government. Paris: OECD.

Scruggs, L. (2007) 'Welfare state generosity across space and time', in J. Clasen and N. A. Siegel (eds) Investigating Welfare State Change: The 'Dependent Variable Problem' in Comparative Analysis, pp. 133-65. Cheltenham: Edward Elgar.

Scruggs, L. (2014) Social Welfare Generosity Scores in CWED 2: A Methodological Genealogy. CWED Working Paper Series - WP 01 - February 2014.

Scruggs, L., Jahn, D. and Kuitto, K. (2014) Comparative Welfare Entitlements Dataset 2. [Version 2014-03]. University of Connecticut/University of Greifswald.

Siegel, N. A. (2007) 'When (only) money matters: the pros and cons of expenditure analysis', in J. Clasen and N. A. Siegel (eds) Investigating Welfare State Change: The 'Dependent Variable Problem' in Comparative Analysis., pp. 43-71. Cheltenham: Elgar.

Swank, D. H. (2011) 'Activating Workers? The Political Economy of Active Social Policy in Postindustrial Democracies', in D. Brady (ed.) Comparing European Workers Part B: Policies and Institutions, pp. 9-51. Bingley: Emerald.

Taylor-Gooby, P. (ed.) (2004) New Risks, New Welfare: The Transformation of the European Welfare State. Oxford: Oxford University Press.

Tepe, M. and Vanhuysse, P. (2010) 'Elderly bias, new social risks and social spending: change and timing in eight programmes across four worlds of welfare, 1980-2003', Journal of European Social Policy 20(3): 217-34. 
van Lancker, W. and Ghysels, J. (2014) 'Who Benefits from Investment Policies? The Case of Family Activation in European Countries', in B. Cantillon and F. Vandenbrouck (eds)

Reconciling Work and Poverty Reduction: How Successful are European Welfare States?, pp. 212 37. Oxford: Oxford University Press.

Vandenbroucke, F. and Vleminckx, K. (2011) ‘Disappointing poverty trends: is the social investment state to blame?', Journal of European Social Policy 21(5): 450-71.

Vis, B. (2010) Politics of Risk-taking: Welfare State Reform in Advanced Democracies. Amsterdam: Amsterdam University Press.

World Bank (2001) Social Protection Sector Strategy: From Safety Net to Springboard. Washington, DC: World Bank. 